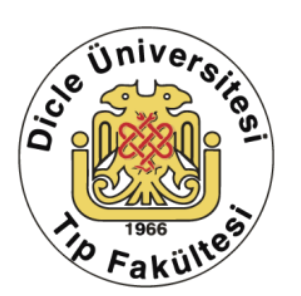

\title{
Evaluation of the effect of red cell distribution width on the development of acute renal failure in patients with sepsis
}

\author{
Ali Veysel Kara', Sema Tanrikulu², Emre Aydın ${ }^{3}$, Fatma Aydın ${ }^{3}$, Hikmet Soylu ${ }^{3}$ \\ Yaşar Yıldırım¹, Zülfükar Yılmaz', Ali Kemal Kadiroğlu¹, Mehmet Emin Yılmaz' \\ 1 Dicle University Faculty of Medicine, Department of Nephrology, Diyarbakır, Turkey \\ 2 Gazi Yaşargil Research Hospital, Diyarbakır, Turkey \\ 3 Dicle University Faculty of Medicine, Department of Internal Medicine, Diyarbakır, Turkey \\ Received: 27.12.2016; Revised: 17.04.2017; Accepted: 04.05.2017
}

\begin{abstract}
Objective: Acute kidney injury (AKI) is an important clinical entity that is known to increase mortality in patients with sepsis. Erythrocyte maturation and proliferation are inhibited by pro-inflammatory cytokines; these cytokines exert effects on red cell distribution width (RDW) well. Based on this knowledge; our aim in this study was to evaluate the impact of RDW on acute kidney injury in patients with sepsis.

Methods: 120 patients diagnosed with sepsis and admitted to intesive care unit (ICU) and treated between 2009-2013 were retrospectively evaluated. Patients were divided into two groups as follows: group 1 (RDW $\geq 16.8$ ) and group 2 $(\mathrm{RDW}<16.8)$. Multiple logistic regression analysis was used to determine the association between RDW and AKI and mortality.

Results: There was a statistically significant relationship between AKI and RDW $(p<0.001,0 R=11.52)$ but there were no statistically significant relationship between AKI and sex, age, serum lactate levels as well as SOFA score. Also, there were statistically significant relationship between mortality and RDW ( $\mathrm{p}=0.044,0 \mathrm{R}=5)$, serum lactate levels $(\mathrm{p}=0.030)$ and SOFA score $(\mathrm{p}<0.001)$. RDW was found associated with both AKI and mortality.

Conclusions: Results suggest that RDW is an important parameter for predicting development of AKI and mortality in ICU patients with sepsis.
\end{abstract}

Keywords: Acute kidney injury, Sepsis, Red cell distribution width

DOI: $10.5798 /$ dicletip.319769

Yazışma Adresi / Correspondence: Ali Veysel Kara, Dicle University Faculty of Medicine, Department of Nephrology, Diyarbakır, Turkey e-mail: aliveyselkara@hotmail.com 


\section{Eritrosit dağılım genişliğinin sepsisli hastalarda akut böbrek hasarı gelişimi üzerine etkisinin değerlendirilmesi}

\section{Özet}

Amaç: Akut böbrek hasarı (AKI) sepsisli hastalarda mortaliteyi arttırdı̆̆ı bilinen önemli bir klinik tablodur.Eritrosit maturasyonu ve profilerasyonu, proinflamatuar sitokinler tarafından inhibe edilir. Bu sitokinler eritrosit dağllım genişliği üzerinde etkilidirler. Bu ilgiye dayanarak sepsisli hastalarda eritrosit dağılım genişliğinin (rRDW) akut böbrek hasarı gelişimi üzerine etkisini değerlendirmeyi amaçladık.

Yöntemler: 2009-2013 yılları arasında sepsis tanısı olan ve yoğun bakım ünitesine kabul edilen 120 hastayı retrospektif olarak inceledik. hastaları grup $1(\mathrm{RDW} \geq 16.8)$ ve grup $2(\mathrm{RDW}<16.8)$ olarak iki gruba ayırdık. $\mathrm{RDW}$, akut böbrek hasarı ve mortalite arasındaki ilişkiyi belirlemek için multiple lojistik regresyon analizi kullandık.

Bulgular: Akut böbrek hasarı ve RDW arasında istatiksel olarak anlamlı ilişki tespit ettik ( $\mathrm{p}<0.001,0 R=11.52)$ ancak akut böbrek hasarı ve cinsiyet, yaș, serum laktat seviyeleri ve SOFA skoru arasında anlamlı ilișki yoktu. Aynı zamanda, mortalite ve RDW arasında ( $\mathrm{p}=0.044, \mathrm{OR}=5)$, mortalite ve serum laktat seviyeleri arasında $(\mathrm{p}=0.030)$ ve mortalite ve SOFA skoru arasında ( $\mathrm{p}<0.001$ ) anlamlı ilişki gösterildi. RDW nin hem akut böbrek hasarı hem de mortalite ile ilişkili oldugu gösterildi.

Sonuç: Bulgular RDW nin yoğun bakım ünitesindeki sepsisli hastalarda mortalite ve akut böbrek hasarını tahmin etmede önemli bir parametre oldugunu göstermiştir

Anahtar kelimeler: Akut Böbrek Hasarı, Sepsis, Eritrosit dağılım genişliği

\section{INTRODUCTION}

Sepsis is a fatal infectious disease that can cause hemodynamic changes, multiple organ dysfunction and shock $^{1}$. Sepsis has high mortality rates, therefore, requires early diagnosis and treatment in intensive care units. Sepsis develops due to the interaction between the causative organism and the immunologic, inflammatory and coagulation responses of the host. The target tissue is the vascular endothelium, and almost all mediators are effective on the vascular endothelium. Endothelial cells secrete important molecules that regulate both coagulation and inflammation ${ }^{2,3}$. In addition, shunts have been detected in the microvascular circulation in severe sepsis and septic shock ${ }^{4}$. These shunts may occur due to microvascular lumen obstruction, which is caused by endothelial cell swelling, by disruption of flow, caused by the binding of activated leukocytes to the endothelium, or by the deterioration of the elasticity of the wall 5 .
The most common causes of sepsis are bacteria, fungi, viruses and parasites, respectively ${ }^{6}$. However, microbiological evidence is unnecessary for the diagnosis of sepsis ${ }^{7}$. It has been reported that etiological factors cannot be determined in 30-50 \% of patients with sepsis $^{8,9}$.

Acute kidney injury (AKI) is one of the key factors determining morbidity and mortality in sepsis ${ }^{10}$. Due to the recent progress made in cell biology, the pathophysiology of sepsis has become better understood. Mediators and cytokines involved in the pathophysiology of sepsis has been determined and their effects on metabolic changes in the body and other mechanisms of action have been defined ${ }^{11,12}$. Sepsis and especially septic shock are important causes of AKI. AKI due to sepsis is one part of multi organ failure and has a significant effect on mortality ${ }^{13}$.

Erythrocyte distribution width (RDW), which is determined by the complete blood count (CBC), is an important index showing the distribution of the sizes of circulating red blood cells. RDW within normal limits indicates that the sizes of 
the erythrocytes are in a regular distribution. RDW is used in the diagnosis of anemia, and increases in RDW are observed in hemolysis and erythrocyte production disorders ${ }^{14}$.

The systemic inflammatory response affects the function of bone marrow and iron metabolism 15,16 . It is known that prionflammatory cytokines, which are related to increases in RDW inhibit erythrocyte maturation and proliferation induced by erythropoietin and down-regulate erythropoietin receptor expression ${ }^{17}$. Furthermore, it is thought that oxidative stress causes increased RDW by shortening the lifetime of erythrocytes and thus enhancing the release of large, premature erythrocytes to the peripheral circulation ${ }^{18}$. Increased RDW indicates an increased diversity in the size of the erythrocytes, which is a situation that is also known as anisocytosis. Increased RDW occurs especially in nutritional deficiency such as iron, folate and vitamin b12. Increased RDW is not only observed in hematological diseases, but has also been observed in pulmonary embolism $^{19}$, acute renal failure ${ }^{20}$, pulmonary arterial hypertension ${ }^{21}$, stroke ${ }^{22}$ and peripheral arterial diseases ${ }^{23}$. Increased RDW levels increase the risk of death due to any cause in addition to the increased risk of cardiovascular death. The aim of this study is to evaluate the impact of RDW on acute kidney injury in patients with sepsis.

\section{METHODS}

The records of 120 patients with a diagnosis of sepsis who were admitted to the internal medicine intensive care unit and treated between 2009-2013 in Dicle University Faculty of Medicine Research and Application Hospital were retrospectively evaluated. This study was approved by the local ethics committee (357).

The study inclusion criteria were as follows: patients between the ages of 18-70, patients who had two or more systemic inflammatory response syndrome (SIRS) findings with the clinical and/or bacteriological evidence of infection ( fever $>38 \mathrm{C}$ or fever $<36 \mathrm{C}$ ), heart rate $>90 / \mathrm{min}$, respiratory rate $>20 / \mathrm{min}$ or $\mathrm{PaCO} 2<32 \mathrm{mmHg}$ or mechanical ventilation requirement, $\quad \mathrm{WBC}>12000 / \mathrm{mm} 3$ or $<4000 / \mathrm{mm} 3$, platelet count $<100000 / \mathrm{mm} 3$ or sepsis induced coagulopathy, and hypoperfusion findings, including oliguria $\quad<0.5$ $\mathrm{ml} / \mathrm{kg} / \mathrm{h})$, variable mental status or serum lactate level $>2.2 \mathrm{mmol} / \mathrm{L}$.

The study exclusion criteria were as follows: fasting $>15$ days, blood products transfusion the week prior to ICU admission, bleeding $>10 \%$, history of hematological disease, recent history of chemotherapy, cardiogenic shock, hepatic cirrhosis, pregnancy or drug usage, which can change red blood cell morphology.

The files of 565 patients with a diagnosis of sepsis were reviewed retrospectively. 445 patients were excluded from the study according to aforementioned criteria. The demographic characteristics, sepsis etiology and comorbid conditions of 120 patients who meet the criteria were obtained from the patient files. The values of RDW, Hgb, Htc, MCV, CRP and creatinine at ICU admission and at 48 hours after admission were recorded from the patient files. The SOFA score for each patient was calculated. These values, including the SOFA score, were also recorded at ICU follow up. Patients were divided into two groups as follows: group 1 (RDW $\geq 16.8)$ and group 2 (RDW <16.8). AKI was investigated in both groups; patients with a $0.3 \mathrm{mg} / \mathrm{dl}$ or greater increase in serum creatinine within 48 hours were considered as having AKI.

SPSS (Statistical Package for Social Sciences for Windows version 16) was used for statistical analysis. A Student's $t$ test and multiple logistic regression analysis were used. Data were expressed as means \pm SD. Odds Ratio values were calculated to evaluate the relationship between RDW and AKI. P values $<0.005$ were considered statistically significant at the $95 \%$ confidence interval. 
Kara A.V., Tanrıkulu S., Aydın E., Aydın F., Yıldırım Y., Zulfukar Y., Kadiroğlu A.K., Yılmaz M.E.

Table 1: Demographic characteristics, laboratory results, SOFA scores and average lengths of stay in the intensive care unit for groups $1(\mathrm{RDW}>16.8)$ and $2(\mathrm{RDW}<16.8)$.

\begin{tabular}{llll}
\hline Variables & Group 1 (n:66) & Group 2 (n:54) & $\boldsymbol{P}$ \\
\hline Sex(m/f) & $37 / 29$ & $32 / 22$ & 0,724 \\
Age(years) & $50,66 \pm 14,79$ & $49,59 \pm 13,93$ & 0,685 \\
Hgb (g/dl) & $11,39 \pm 2,05$ & $12,28 \pm 1,91$ & $\mathbf{0 , 0 1 6}$ \\
MCV (fl) & $82,75 \pm 7,70$ & $87,52 \pm 5,20$ & $<\mathbf{0 , 0 0 1}$ \\
CRP(mg/dl) & $14,43 \pm 10,44$ & $14,51 \pm 11,85$ & 0,972 \\
Creatinin (mg/dl) & $2,17 \pm 1,95$ & $1,38 \pm 1,49$ & $\mathbf{0 , 0 1 6}$ \\
$\begin{array}{l}\text { SOFA score } \\
\text { Avarege length of stay in } \\
\text { the ICU (days) }\end{array}$ & $5,09 \pm 4,39$ & $3,14 \pm 3,95$ & $\mathbf{0 , 0 1 3}$ \\
& $18,16 \pm 15,82$ & $15,68 \pm 10,02$ & 0,320 \\
\hline
\end{tabular}

\section{RESULTS}

Of the 120 patients with sepsis that were included in this study, 69 (57.5\%) were male and 51 (42.5\%) were female. The mean age of the patients was $50.18 \pm 14.36$ years. There were 66 patients in group $1(\mathrm{RDW} \geq 16.8)$ and 54 patients in group 2 (RDW<16.8). According to the etiology of sepsis of the patients in group 1, 38 had lung infection, 14 had urinary tract infection, 3 had gastrointestinal tract infection and 12 had other system infections. In group 2, 21 patients had lung infection, 13 had urinary tract infection, 3 had gastrointestinal tract infection and 18 had other system infections $(p=0.292)$.

Table 2: Multivariate logistic regression analysis for AKI.

\begin{tabular}{lccc}
\hline Variables & OR & $\mathbf{9 9 5}$ CI & P \\
\hline RDW $\geq 16.8 \%$ & 11.52 & $4.62-28.72$ & $<0.001$ \\
Gender (Female vs Male) & 0.21 & $0.50-2.92$ & 0.671 \\
Age $>65$ years & 0.72 & $0.20-2.57$ & 0.619 \\
Lactate $>2$ mmol/L & 1.34 & $0.52-3.45$ & 0.542 \\
SOFA score $\geq 7$ & 1.57 & $0.48-5.10$ & 0.453
\end{tabular}

OR, odds ratio; $\mathrm{CI}$, confidence interval
Table 3: Multivariate logistic regression analysis for mortality.

\begin{tabular}{lccc}
\hline Variables & OR & \%95 CI & P \\
\hline RDW $\geq 16.8 \%$ & 5.00 & $1.04-24.01$ & 0.044 \\
\hline Gender (Female vs Male) & 0.38 & $0.12-1.14$ & 0.087 \\
\hline Age $>65$ years & 2.34 & $0.58-9.47$ & 0.232 \\
\hline Lactate $>2$ mmol/L & 3.24 & $1.12-9.39$ & 0.030 \\
\hline SOFA score $\geq 7$ & 21.21 & $5.48-82.02$ & $<0.001$ \\
\hline AKI & 3.23 & $0.87-11.94$ & 0.079 \\
\hline
\end{tabular}

$\mathrm{OR}$, odds ratio; $\mathrm{CI}$, confidence interval

When we evaluated patients according to comorbid diseases accompanying sepsis, we have found that in group 1, 6 patients had congestive heart failure $(9.09 \%), 5$ had diabetes mellitus $(7.57 \%), 3$ had hypertension (4.54\%), 12 had chronic obstructive pulmonary disease $(18.18 \%), 4$ had coronary artery disease (6.06\%), 8 had neurological disease $(12.12 \%), 2$ had chronic kidney disease (3.03\%) and 1 had chronic liver disease $(1.51 \%)$. In group 2, 14 patients had diabetes mellitus (25.92\%), 6 had hypertension $(11.11 \%), 1$ had coronary artery disease (1.85\%), 8 had neurological disease (14.81\%), and 1 had chronic liver disease (1.85\%). All of the patients with congestive heart failure 
and/or COPD were in group 1. In addition, there were 5 patients with coronary artery disease, and 4 of them were in group 1 . We note that these three significant comorbid conditions may be associated with an increase in RDW. There was a statistically significant difference between groups 1 and 2 with respect to comorbid diseases $(\mathrm{p}=0.016)$.

Of the patients in group 1 (RDW>16.8), 37 were male, 29 were female, the mean age was $50.6614 \pm 79$ years, the mean RDW was 19.38 \pm 2.94 , the mean Hgb value was $11.39 \pm 2.05$, the mean MCV was $82.75 \pm 7.70$, the mean CRP value was $14.43 \pm 10.44$, the mean SOFA score was $5.09 \pm 4.39$, the mean creatinine value was $2.17 \pm 1.95$ and the average length of stay in the ICU was $18.16 \pm 15.82$ days. Of the patients in group 2, 32 were male, 22 were female, the mean age was $49.59 \pm 13.93$ years, the mean RDW was $15.70 \pm 0.75$, the mean $\mathrm{Hgb}$ was $12.28 \pm 1.91$, the mean MCV was 87.52 \pm 5.20 , the mean CRP value was $14.51 \pm 11.85$, the mean SOFA score was $3.14 \pm 3.95$, the mean creatinine value was $1.38 \pm 1.49$ and the average length of stay in the ICU was $15.68 \pm$ 10.02 days. There were statistically significant differences between groups with respect to RDW, Hb, MCV, SOFA score and creatinine values. The differences between the other variables were not statistically significant. The results are summarized in table 1 . Thirty-seven patients in group 1 had AKI while 18 patients in group 2 had AKI ( $p=0.013)$. The distribution of the patients into subgroups with respect to RDW and AKI is shown in figure 1.

The mortality rate in group 1 was $39.4 \%$, and their discharge rate was $60.6 \%$. For group 2, the mortality rate was $16.7 \%$ and the discharge rate was $83.3 \%$. The mortality rate was significantly higher in group $1 \quad(p=0.006)$ (figure 2).

In multiple logistic regression analysis; there was a statistically significant relationship between AKI and RDW ( $p<0.001,0 R=11.52)$ but there were no statistically significant relationship between AKI and sex, age, serum lactate levels and SOFA score (table 2). Also, there were statistically significant relationship between mortality and RDW $(p=0.044,0 R=5)$, serum lactate levels $(\mathrm{p}=0.030)$ and SOFA score $(\mathrm{p}<0.001)$ (table 3). RDW was found associated with both AKI and mortality.

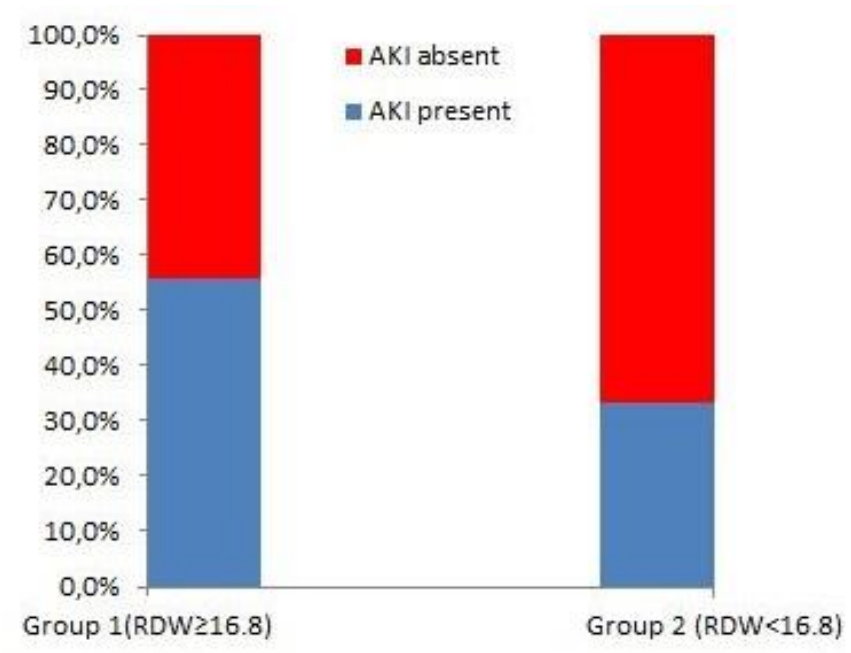

Figure 1. Distribution of the patients into subgroups with respect to RDW and AKI.

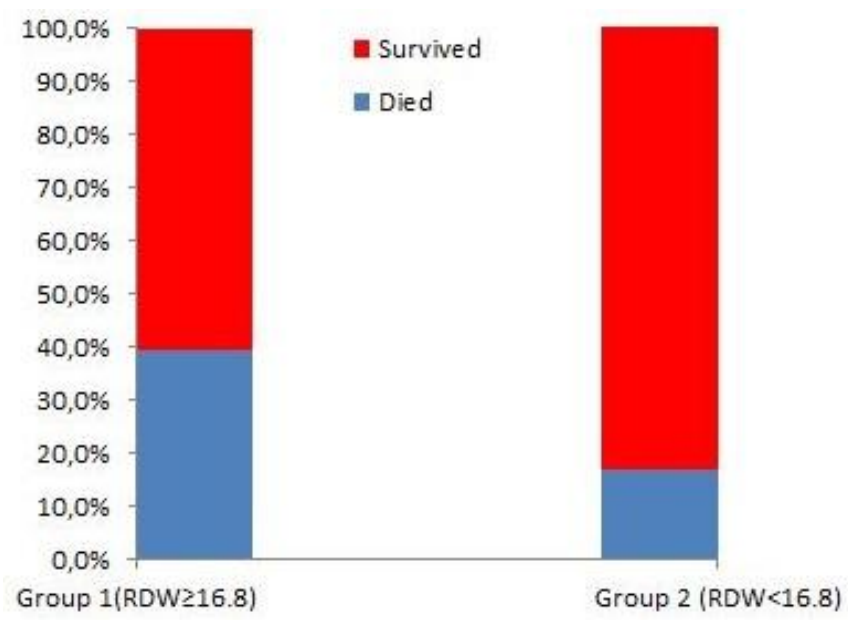

Figure 2. Distribution of the patients into subgroups with respect to RDW and mortality

\section{DISCUSSION}

The causes of sepsis are quite complex. Sepsis is a life-threatening disease associated with multiple organ failure, and its follow-up and 
treatment are carried out in the intensive care unit. Due to the dissemination of bacterial infection and the endothelial response to this infection, sepsis often involves multiple organs. The kidney is one of the most targeted organs in sepsis. Acute kidney injury (AKI) occurs in $5 \%$ of hospitalized patients and in $30 \%$ of ICU patients, and it is one of the key factors determining morbidity and mortality 24 . Approximately $15-20 \%$ of all patients hospitalized in the ICU will develop sepsisinduced AKI, and based on the severity of the damage the mortality of sepsis-induced AKI has been reported to vary between $20.9 \%$ and $56.8 \%$ 25-27. Despite recent advancements in advanced renal replacement technologies, the mortality rate of sepsis remains high, and therefore, the early diagnosis of AKI is very important. The red cell distribution width (RDW) may increase in conditions other than hematological diseases, including anemia, hemolysis and erythrocyte production disorders. The inflammatory process is one of the condition that may cause an increase in RDW. Based on this knowledge, in this retrospective study we investigated the effect of RDW on the development of acute kidney injury in patients with sepsis. The mean age of the patients evaluated in this study (50.18 \pm 14.36 years) was significantly younger than the mean age of the patients in most published studies regarding AKI and sepsis ${ }^{28,29}$. There was no statistically significant difference between our groups (RDW $\geq 16.8$ and RDW $<16.8$ ) according to gender. In multiple logistic regression analysis; there was a statistically significant relationship between AKI and RDW $(\mathrm{p}<0.001)$ but there were no statistically significant relationship between AKI and sex, age, serum lactate levels and SOFA score (table 2). Also, there were statistically significant relationship between mortality and RDW ( $p=0.044)$, serum lactate levels $(p=0.030)$ and SOFA score $(\mathrm{p}<0.001)$ (table 3$)$. RDW was found associated with both AKI and mortality.
In the current study, we found multiple comorbid diseases in both groups of patients. When evaluating the etiologies of sepsis in our study groups, we found that pulmonary and urinary tract infections were among the most common causes, respectively, in both groups. These etiologic causes are consistent with the literature ${ }^{30,31}$. RDW was increased in all of the patients with heart failure and/or chronic obstructive pulmonary disease. Four of the 5 patients with coronary artery disease had increased RDW values. All of the patients with heart failure and chronic obstructive pulmonary disease were in group 1 (RDW $\geq 16.8$ ). In addition, 4 of the 5 patients with coronary artery disease were in group 1 . Therefore, the significantly increase in RDW values in group 1 may be due to the comorbidities of the patients in this group.

CRP is an important diagnostic and follow-up parameter in sepsis. In our study, CRP levels were elevated in both groups and there was no significant difference between the two groups, which is similar to previously published data ${ }^{20,31}$. In addition, studies have reported that the mean CRP value was significantly higher in patients with elevated $\mathrm{RDW}^{32}$. In the current study, we found that in group 1, RDW was $19.38 \pm 2.94 \%$, hemoglobin was $11.39 \pm 2.05$ $\mathrm{g} / \mathrm{dl}$ and MCV was $82.75 \pm 7.70 \mathrm{fl}$. In group 2, RDW was $15.70 \pm 0.75 \%$, Hgb was $12.28 \pm 1.91$ gr/dl and MCV was $87.52 \pm 5.20$ fl. There was a statistically significant difference between the groups with respect to these three variables, and these differences were consistent with previously published data ${ }^{28,32}$.

The SOFA score, which is used to assess the prognosis of patients with severe sepsis, is an important parameter that is highly related to mortality. In our study, there was a statistically significant difference in the SOFA scores between the groups, and the SOFA score was higher in group $1(\mathrm{p}=0.013)$. In a study by Esper R.C. et al, the RDW values were significantly higher in ICU patients with sepsis 
than in those without sepsis. In addition, they have found that RDW values were higher in patients with elevated SOFA scores ${ }^{33}$. In our current study, we found that patients with sepsis had elevated SOFA scores, which was similar to previously published data ${ }^{30,31}$.

The results of the current study suggest that an increase in RDW is associated with the increase in the risk of developing AKI $(p<0.001$, OR: 11.52). Lippi G. et al. reported similar findings. They found that GFR levels decrease progressively $(\mathrm{p}<0.001, \quad \mathrm{OR}$ : 1.982) in accordance with an increase in RDW independent of age, gender, MCV and hemoglobin values ${ }^{28}$. The results of the study by Lippi G. et al. have been supported by other studies $^{31,34}$. However, there are some published studies that show no correlation between RDW and renal function tests ${ }^{20}$.

It is important to evaluate the relationship between RDW and mortality as well as the relationship between RDW and AKI. In our current study, there was a statistically significant difference in the mortality rate between the two groups $(\mathrm{p}=0.006,0 \mathrm{R}: 3.250)$. We found that the mortality rate increased with increasing RDW levels, which is consistent with the literature $29,30,35$. A meta-analysis by Patel K.V. et al found that for every $1 \%$ increase in RDW, there is a $14 \%$ increase in mortality ${ }^{36}$. Our current study and the results of previously published studies support that an increase in RDW is closely related to mortality.

In conclusion, results of the current study indicate that an increase in RDW leads to a increase in the risk of developing AKI $(p<0.001$, OR: 11.52). RDW can be an important parameter that is used to predict the development of AKI and mortality in ICU patients with sepsis. However, further largescale studies relevant to this topic are needed.

Declaration of Conflicting Interests: The authors declare that they have no conflict of interest.

Financial Disclosure: No financial support was received.

\section{KAYNAKLAR}

1. Yalçın AN, Hayran M, Unal S. Economic analysis of nosocomial infections in a Turkish university hospital. J Chemother.1997; 9: 411-4,

2. Russel J.A. Management of sepsis. N Engl J Med 355:1699-1713; 2006.

3. Peters K, Urgen RE, Brunner J, et al. Molecular basis of endothelial dysfunction in sepsis. Cardiovascular Research 60: 49-57; 2003.

4. De Backer, D., Creteur J, Preiser JC, et al. Microvascular blood flow is altered in patients with sepsis. Am J Respir Crit Care Med, 2002; 166: p.98-104.

5. Lehr, H.A., F. Bittinger, and C.J. Kirkpatrick. Microcirculatory dysfunction in sepsis: a pathogenetic basis for therapy? J Pathol, 2000; 190:p.373-86.

6. Annane, D., Aegerter P, Jars-Guincestre MC, et al. Current epidemiology of septic shock: the CUB-Rea Network. Am J Respir Crit Care Med, 2003; 168:p.16572.

7. Llewelyn M, Cohen J. Diagnosis of infection in sepsis. Intensive Care Med 2001; 27 (Suppl 1):S10- S32.

8. Rangel-Frausto MS, Pittet D, Costigan M, et al. The natural history of the systemic inflammatory response syndrome (SIRS). A prospective study. Jama, 1995; 273 : p.117-23.

9. Brun-Buisson C, Doyon F, Carlet J. et al. Incidence, risk factors, and outcome of severe sepsis and septic shock in adults. A multicenter prospective study in intensive care units. French ICU Group for Severe Sepsis. Jama, 1995; 274: p.968-74.

10. Wardle En. Acute renal failure and multiorganfailure. Nephron 66: 380-5; 1994.

11. Bone RC: Sepsis and Septic Shock. In Infectious Disease 1993; 3:5-25.

12. Young LS. Sepsis Syndrome. In: Mandell GL, Bennett JE, Dalin R. Principles and Practice of Infectious Disease 4. Ed. New York. Churchill Livingstone 1995; 690-705.

13. Goldfarb S. Golper TA. Proinflammatory cytokines andsepsis. J Am Soc Nephrol 1994; 5: 228-32,

14. Bessman JD, Gilmer PR, Jr., Gardner FH. Improved classification of anemias by MCV and RDW. Am J Clin Pathol 1983; 80: 322-6.

15. Chiari MM, Bagnoli R, De Luca PD et al. Influence of acute inflammation on iron and nutritional status indexes in older inpatients. J Am Geriatr Soc 1995, 43:767-71.

16. Deswal A, Petersen NJ, Feldman AM, et al. Cytokines and cytokine receptors in advanced heart failure: an analysis of the cytokine database from the Vesnarinone trial (VEST). Circulation 2001; 103: 2055-9. 
17. Pierce CN, Larson DF: Inflammatory cytokine inhibition of erythropoiesis in patients implanted with a mechanical circulatory assist device. Perfusion 2005; 20: 83-90.

18. Ghaffari S: Oxidative stress in the regulation of normal and neoplastic hematopoiesis. Antioxid Redox Signal 2008; 10:1923-40.

19. Zorlu A, Bektasoglu G, Guven FM, et al. Usefulness of admission red cell distribution width as a predictor of early mortality in patients with acute pulmonary embolism. Am J Cardiol 2012; 109:128-34.

20. Oh HJ, Park JT, Kim JK, et al. Red blood cell distribution width is an independent predictor of mortality in acute kidney injury patients treated with continuous renal replacement therapy. Nephrol Dial Transplant 2012; 27: 589-94.

21. Rhodes CJ, Wharton J, Howard LS, et al. Red cell distribution width outperforms other potential circulating biomarkers in predicting survival in idiopathic pulmonary arterial hypertension. Heart 2011;97: 1054-60.

22. Ani C, Ovbiagele B: Relation of baseline presence and severity of renal disease to long-term mortality in persons with known stroke. J Neurol Sci 2010; 288:123-8

23. Ye Z, Smith C, Kullo IJ. Usefulness of red cell distribution width to predict mortality in patients with peripheral artery disease. Am J Cardiol 2011; 107:1241-5.

24. Joannidis M, Metnitz PG. Epidemiology and natural history of acute renal failure in the ICU. Crit Care Clin 2005; 21: 239-49.

25. Wan L, Bagshaw SM, Langenberg C, et al. Pathophysiology of septic acute kidney injury: what do we really know? Crit Care Med. 2008 Apr;36 (4 Suppl): 198-203.

26. Uchino S, Kellum JA, Bellomo $\mathrm{R}$ et al. Acute renal failure in critically ill patients: a multinational, multicenter study. Beginning and Ending Supportive Therapy for the Kidney (BEST Kidney) Investigators. JAMA. 2005 Aug 17; 294: 813-8.

27. Ostermann M, Chang RW. Acute kidney injury in the intensive care unit according to RIFLE.Crit Care Med. 2007 Aug;35: 1837-43; quiz 1852.
28. Lippi G, Targher G, Montagnana M, et al. Relationship between red blood cell distribution width and kidney function tests in a large cohort of unselected outpatients. Scand J Clin Lab Invest 2008; 68:745-8.

29. Lee JH, Chung HJ, Kim K, et al. Red cell distribution width as a prognostic marker in patients with community-acquired pneumonia. Am J Emerg Med. 2013 Jan;31: 72-9. doi: 10.1016/j.ajem. 2012.06.004.

30. Kim CH, Park JT, Kim EJ, et al. An increase in red blood cell distribution width from baseline predicts mortality in patients with severe sepsis or septic shock. Crit Care. 2013 Dec 9;17: R282.

31. Sadaka F, O'Brien J, Prakash S. Red cell distribution width and outcome in patients with septic shock. J Intensive Care Med. 2013 Sep-Oct; 28:307-13.

32. Seyhan EC, Özgül MA, Tutar N, et al. Red blood cell distribution and survival in patients with chronic obstructive pulmonary disease. COPD. 2013 Aug;10: 416-24.

33. Esper RC, Domínguez VC, Córdova LDC, et al. Red blood cell distribution width changes in septic patients Revista de la Asociación Mexicana de Medicina Crítica Y TERAPIA INTENSIVA Vol. XXII, Núm. 1 / Ene.-Mar. 2008 pp 20-25

34. Forhecz Z, Gombos T, Borgulya G, et al. Red cell distribution width in heart failure: prediction of clinical events and relationship with markers of ineffective erythropoiesis, inflammation, renal function, and nutritional state. Am Heart J 2009; 158:659-66.

35. Kim J, Kim K, Lee JH, et al. Red blood cell distribution width as an independent predictor of all-cause mortality in out of hospital cardiac arrest. Resuscitation. 2012 Oct;83:1248-52. doi: 10.1016/ j.resuscitation. 2012.01.038.

36. Patel KV, Semba RD, Ferrucci L, et al. Red cell distribution width and mortality in older adults: a meta-analysis. J Gerontol A Biol Sci Med Sci. 2010 Mar;65: 258-65. 